\title{
PEMBERDAYAAN KELOMPOK TANI SAWAH PAYO KABUPATEN TANAH DATAR DALAM PELATIHAN PEMBUATAN RHIZOKOMPOS
}

\author{
Yulmira Yanti ${ }^{1 *}$, Hasmiandy Hamid ${ }^{1}$, Yaherwandi ${ }^{1}$, Noveriza Hermeria ${ }^{2}$ \\ 1) Program Studi Proteksi Tanaman Fakultas Pertanian Universitas Andalas Padang 25163 \\ 2) Mahasiswa Program Studi Proteksi Tanaman Fakultas Pertanian Universitas Andalas Padang 25163 \\ "Email:mira23@gr.unand.ac.id ; yy.anthie79@gmail.com
}

\begin{abstract}
Abstrak
Kelompok tani Sawah Payo Nagari Gunung Rajo Kecamatan Batipuh, Kabupaten Tanah Datar mempunyai potensi dalam produksi pupuk organik, hal ini didukung oleh sisa hasil pertanian seperti jerami padi dan gulma tanaman pahitan Tithonia diversifolia, serta limbah peternakan (kotoran hewan) yang melimpah. Pemanfaatan limbah pertanian, tanaman gulma , maupun peternakan masih belum maksimal. Pengolahan limbah pertanian dan peternakan menjadi kompos yang dilakukan oleh sebagian besar petani di Nagari Gunung Rajo belum menggunakan proses fermentasi, sehingga hasil dan kualitasnya kurang maksimal. Tujuan kegiatan pemberdayaan kelompok tani ini adalah memberikan pengetahuan tentang proses pembuatan pupuk organik dari penyedian bahan baku, pembuatan bio-aktivator, dan pengemasan hasil produksi. Metode yang digunakan dengan pelatihan terstruktur dan praktik langsung pembuatan pupuk organik atau yang lebih dikenal dengan kompos. Hasil yang diperoleh dari kegiatan pemberdayaan ini adalah kelompok tani mampu membuat pupuk organik rizokompos berbahan limbah pertanian, gulma, limbah peternakan dan rizobakteri secara mandiri dengan kualitas hasil produksi yang baik yang mampu meningkatkan hasil pendapatan masyarakat setempat.
\end{abstract}

Kata kunci: pemberdayaan, pupuk organik, rizokompos

\section{PENDAHULUAN}

Nagari Gunung Rajo yang terletak di Kabupaten Tanah Datar Sumatera Barat memiliki sumber daya alam yang baik terutama untuk perkembangan tanaman. Berbagai jenis tanaman dapat tumbuh di daerah tersebut, termasuk tumbuhnya gulma yang selama ini tidak pernah diperhatikan keberadaannya oleh masyarakat. Salah satu jenis gulma yang keberadaannya sangat melimpah di Nagari Gunung Rajo adalah tanaman pahitan, Tithonia diversifolia, merupakan salah satu jenis tanaman yang baik untuk meningkatkan mutu pupuk kompos.

Sampai saat ini, aspek mutu dan keamanan pangan masih menjadi salah satu kendala utama dalam produksi dan pemasaran sayuran. Penggunaan bahan kimia sintetis yang berlebihan dalam produksi pertanian dapat menurunkan kualitas pangan hasil pertanian sehingga tidak aman untuk dikonsumsi. Selain itu, penggunaan bahan kimia sintetis berlebihan dalam budidaya pertanian dapat mengakibatkan kerusakan lingkungan yang berdampak pada penurunan produktivitas lahan. Disisi lain, biaya produksi menggunakan bahan kimia sintetis lebih mahal (Lestari, 2009)

Masalah yang sering dihadapi petani Gunung Rajo adalah masalah pupuk. Keberadaan pupuk bersubsidi sangat terbatas dengan harga yang relatif tinggi, sehingga diperlukan alternatif lain

$$
\text { Teknologi Tepat Guna }
$$


untuk memenuhi kebutuhan petani sekaligus upaya mengurangi ketergantungan pada penggunaan pupuk kimia (Wijayanto et al. 2018).

Salah satu alternatif dalam pengembangan pertanian yang lebih ramah terhadap lingkungan adalah dengan menerapkan sistem pertanian organik, yang menerapkan teknologi ramah lingkungan dalam mencapai sistem pertanian yang lestari dan berkelanjutan untuk membangun kesuburan tanah jangka panjang. Pertanian organik merupakan sistem pertanian yang menggunakan bahan organik dari residu limbah tanaman atau ternak yang diberikan pada tanah untuk nutrisi tanaman. Sumber bahan organik yang digunakan dapat berasal dari sisa kotoran hewan (pupuk kandang), sisa tanaman, pupuk hijau, sampah kota, limbah industri untuk dijadikan kompos. Penerapan teknologi pengolahan bahan-bahan organik menjadi kompos di kalangan petani masih lemah dan rendah. Hal ini disebabkan karena sebagian besar petani mengetahui teknologi tetapi belum menerapkan karena belum paham teknis pelaksanaannya.

Prihandarini (2005) menyatakan, prospek pengembangan industri pupuk organik sangatlah baik dan menguntungkan, karena dewasa ini sangat diminati oleh para petani untuk meningkatkan efisiensi penggunaan pupuk anorganik yang harganya semakin meningkat. Jenis pupuk organik yang terbaik adalah berupa kompos, karena dapat menyediakan unsur hara bagi tanaman dan memperbaiki struktur maupun kesuburan tanah. Kompos adalah bahan organik yang dapat berupa dedaunan, rumput, jerami, dan kotoran hewan yang telah mengalami proses pelapukan karena adanya interaksi antara mikroorganisme yang bekerja di dalamnya.

Bahan organik yang dapat dijadikan kompos di nagari Gunung Rajo ini diantaranya dengan penggunaan jerami padi dan gulma paitan. Limbah jerami padi sangat mudah didapatkan diareal persawahan sehingga pemanfaatannya dapat mengurangi masalah limbah. Sisa tanaman seperti jerami apabila dikomposkan juga berfungsi sebagai pupuk. Bahan organik seperti limbah tanaman yang telah dikomposkan akan meningkatkan kuantitas dan kualitas hasil tanaman. Studi pemanfaatan bahan organik berarti menunjang sistem budidaya tanaman yang ramah lingkungan dan berkelanjutan.

Bahan organik (kompos jerami) dapat meningkatkan serapan nitrogen sesuai dengan ketersediaan- $\mathrm{N}$ pada tanah bila diberi kompos jerami. Dengan meningkatnya pemberian pupuk NPK maka ketersediaan-N tanah meningkat. Selain itu pemberian kompos dapat memperbaiki struktur tanah sehingga pertumbuhan akar baik dan ditambah dengan ketersediaan nitrogen yang tinggi maka akar akan menyerap unsur nitrogen dengan baik (E. Kaya, 2013)

Kualitas hasil pengomposan tergantung pada kualitas dan jumlah bakteri pengurai yang ada. Semakin banyak bakteri pengurai, semakin baik kualitas kompos tersebut. Kualitas perkembang biakan bakteri selain faktor lingkungan juga dipengaruhi oleh sumber makanan yang tersedia. Semakin baik kualitas sumber makanan, semakin baik pula perkembangbiakan serta jumlah bakteri yang tersedia (Yanti, et al 2019)

Proses fermentasi bahan organik biasanya menggunakan aktivator mikroba. Salah satu fungsi aktivator ini adalah mempercepat proses dekomposisi bahan organik dan meningkatkan kualitas bahan. Prinsip pembuatan kompos adalah pencampuran bahan organik dengan mikroorganisme sebagai bioaktivator. Mikroorganisme tersebut dapat diperoleh dari berbagai sumber, salah satunya dari bakteri inokulan yang berfungsi dalam menjaga keseimbangan karbon dan nitrogen yang merupakan faktor penentu keberhasilan pembuatan kompos (Djuarnani, Kristian, Setiawan, 2005 dan Yuwono, 2005).

Adapun tujuan dari pengabdian masyarakat ini adalah untuk menambah pengetahuan masyarakat bahwasanya gulma dan tanaman lain yang banyak tumbuh di lingkungan sekitar dapat dijadikan sebagai bahan pembuatan kompos serta memberikan penjelasan bagaimana proses pengolahannya hingga menjadi pupuk kompos yang dapat digunakan untuk keperluan budidaya tanaman. Selain itu diharapkan juga masyarakat

$$
\text { Teknologi Tepat Guna }
$$


dapat memanfaatkan pengetahuan dan keterampilan yang telah diberikan untuk dikembangkan menjadi peluang usaha dan menambah nilai jual ekonomis tanaman tersebut.

\section{METODE}

Program pengabdian masyarakat ini dilakukan pada bulan Juli sampai dengan Agustus 2020 di lokasi Kelompok Tani Sawah Payo Kabupaten Tanah Datar Sumatera Barat dengan metode penyuluhan dan demonstrasi. Peserta kegiatan ini ialah Tim Pengabdian Masyarakat Unand, mahasiswa Fakultas Pertanian, Kelompok Tani Sawah Payo serta masyarakat Nagari Gunung Rajo. Kegiatan penyuluhan dilakukan dengan pemberian materi oleh narasumber dan dilanjutkan dengan diskusi perihal pembuatan rizokompos. Sedangkan kegiatan demonstrasi dilakukan setelah penyuluhan selesai diberikan, sehingga masyarakat menjadi lebih paham mengenai bagaimana proses pembuatannya. Demonstrasi tersebut langsung dibantu oleh mahasiswa Fakultas Pertanian Prodi Proteksi Tanaman dan kelompok tani Sawah Payo.

\section{A. Survey Pendahuluan dan Pendekatan Sosial}

Tahap ini bertujuan untuk melakukan komunikasi dan sosialisasi mengenai maksud dan tujuan kegiatan program penelitian melalui ketua kelompok tani serta masyarakat lainnya. Dari kegiatan ini diharapkan terciptanya suatu kerjasama antara masyarakat, unit pengelola penyuluhan berbasis petani dan aparat pemerintah. Selain itu, kegiatan ini akan memperoleh legitimasi bagi semua kegiatan yang berkaitan dengan pelaksanaan penelitian, sehingga dukungan semua pihak dapat diperoleh. Masyarakat bersedia untuk mengikuti kegiatan ini serta menyediakan waktu dan lahan percontohan atau demplot untuk pembuatan kompos.

\section{B. Penyuluhan}

Tim pelaksana kegiatan dengan aparat desa, tokoh masyarakat, para petani dan ibu - ibu PKK berkumpul di Kantor Wali Nagari dan kelompok tani Sawah Payo yang lahannya digunakan sebagai demplot. Kegiatan ini bertujuan untuk memberikan materi penyuluhan berupa: a. Hama dan penyakit yang sering menyerang tanaman padi

b. Dampak negatif penggunaan pupuk kimia dengan dosis tinggi

c. Pemanfatan sisa jerami padi serta gulma paitan sebagai bahan dasar pembuatan kompos yang lebih ramah lingkungan.

d. Pemanfaatan agensia hayati rizobakteri sebagai bahan pembantu pembuatan kompos sebagai dekomposer

\section{Pelatihan}

Pelatihan yang dilaksakan bertujuan untuk menambah wawasan dan pengetahuan petani tentang penggunaan dan pemanfaatan gulma, sisa jerami padi yang sudah tidak dipakai sebagai bahan pembuatan kompos, cara pengolahan dan pembuatan kompos. Pelatihan ini dilakukan pada semua anggota kelompok tani mitra.

\section{Pembuatan Demplot}

Untuk lebih meyakinkan petani padi tentang kemampuan rizokompos, maka dibuat demplot percontohan pembuatan kompos di salah satu lahan milik anggota kelompok tani. Demplot pembuatan kompos dibuat dengan ukuran $2 \times 2 \times 1$ meter. Adapun bahan yang diperlukan dalam pembuatan rizokompos ini adalah Pupuk kandang $250 \mathrm{~kg}$, dedak halus $10 \mathrm{~kg}$, titonia, rinju pahit dan jerami padi 1 ton, tanah humus $20 \mathrm{~kg}$ dan rizobakteri. Sedangkan alatnya adalah terpal, cangkul dan parang. Skema pembutan kompos terdiri dari beberapa lapisan seperti pada gambar.

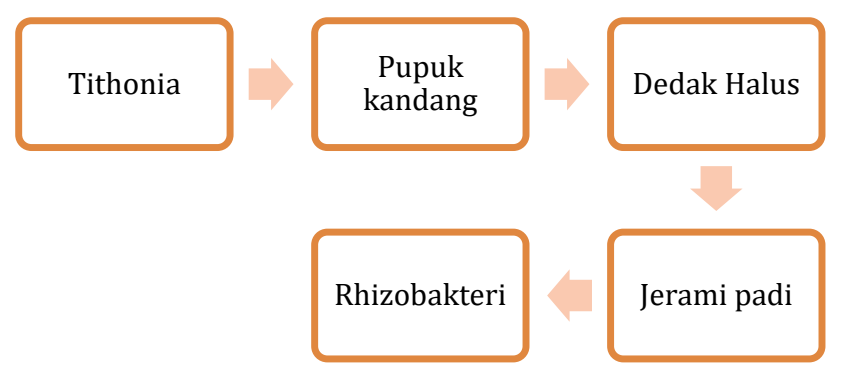




\section{HASIL DAN PEMBAHASAN}

\section{A. Survey Pendahuluan dan Pendekatan Sosial}

Sebelum melaksanakan penelitian, tim melakukan survey dengan mengunjungi lokasi penelitian dan melakukan wawancara bersama wali nagari. Diskusi mengenai permasalahan budidaya tanaman dilakukan sebagai bahan pertimbangan untuk melakukan penelitian. Kelompok tani mitra di Nagari Gunung Rajo merupakan kelompok tani yang mengusahakan budidaya padi sawah. Namun hasil panen dari tahun ke tahun terus menurun. Dari kegiatan survei juga ditemukan bahwa petani tidak melakukan pergiliran tanaman dalam mengolah lahan pertanian. Petani hanya menanam satu jenis tanaman saja dilahan yang digunakan, dan itu diterapkan secara terus menerus.

Kegiatan budidaya seperti ini kurang baik untuk kondisi suatu lahan pertanian. Lahan pertanian perlu diolah dengan menerapkan sistem pergiliran tanaman, yaitu salah satu metode yang sering diterapkan oleh petani dalam rangka untuk mencegah perkembangan hama dan penyakit, memelihara atau memperbaiki kesuburan tanah (ketersediaan hara dan sifat-sifat fisik tanah) serta dapat mengurangi erosi lahan. Dalam sistem ini dilakukan penanaman berbagai tanaman secara bergilir dalam urutan waktu tertentu pada sebidang lahan. Namun kegiatan ini dapat diganti dengan cara memperbaiki kondisi tanah lahan menggunakan pupuk kompos dan penerapan PHT.

Penerapan PHT dengan menggunakan limbah dan rizobakteri telah mendapatkan banyak keberhasilan diantaranya di Nagari Salimpat ( Yanti, et al., 2014) dan di Nagari Aie Dingin (Yanti, et al., 2015) dan di Nagari Sungai Durian (Yanti et al., 2017).

\section{B. Penyuluhan dan diskusi}

Penyuluhan dilakukan di Gedung Balai Serbaguna Nagari Gunung Rajo dengan melibatkan aparat pemerintahan Nagari, Kelompok tani sawah Payo dan masyarakat setempat (Gambar 1). Adapun materi yang diberikan ialah: (1) Pemanfaatan sisa jerami padi serta tanaman gulma sekitar pekarangan; (2) Cara pembuatan Rizokompos; dan
(3) Pemanfaatan sisa peternakan dan (4) Manfaat Rizokompos. Hasil yang diperoleh dari kegiatan ini yaitu masyarakat mempunyai pemahaman baru serta dapat mengasah kemampuan masyarakat dalam mengolah dan memanfaatkan tanaman gulma Tithonia diversivolia, daun paitan, sisa-sisa kotoran peternakan yang dapat dimanfaatkan sebagai pembuatan kompos. Dengan demikian dapat mengurangi ketergantungan terhadap penggunaan pupuk kimia dalam kegiatan budidaya tanaman.

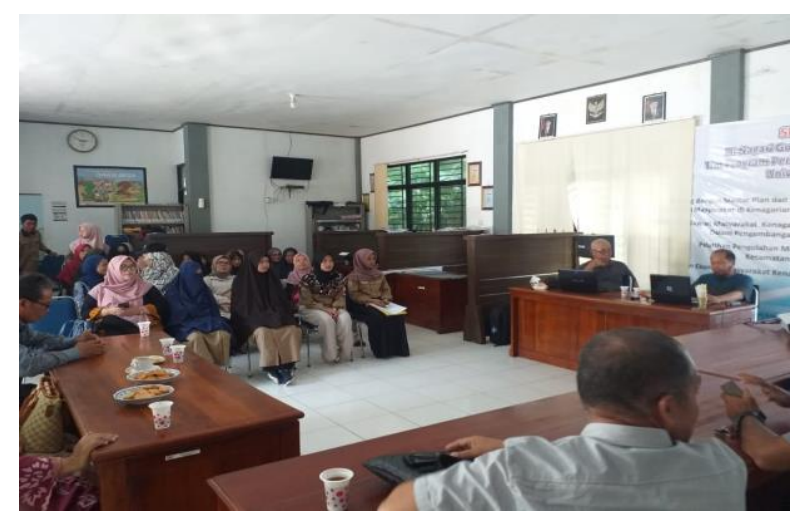

Gambar 1. Penyuluhan dan diskusi dengan aparat pemerintahan Nagari, Kelompok tani sawah Payo dan masyarakat setempat

\section{Pelatihan}

Pada kegiatan ini, petani dilatih dalam pembuatan pupuk kompos dengan memanfaatkan sisa jerami padi, tanamana gulma paitan serta agens hayati rizobakteri yang dapat membantu proses fermentasi pembuatan kompos tersebut. Petani juga diberikan pengetahuan terkait keunggulan dalam penggunaaan agens hayati. Pentingnya peran agens hayati dalam mengendalikan hama dan penyakit tanaman padi juga disampaikan kepada kelompok tani. Untuk mempersiapkan agens hayati, petani cukup diberikan sosialisasi dan simulasi pembuatannya di tahap laboratorium. Untuk pemenuhan kebutuhan selanjutnya, petani dapat memperolehnya dari pihak kampus bersangkutan.

\section{Demonstrasi Pembuatan Kompos}

Demonstrasi dilakukan setelah penyuluhan. Sebelum dilakukan demonstrasi, kelompok tani

$$
\text { Teknologi Tepat Guna }
$$


sawah Payo serta warga lainnya mencari bahanbahan dan membuat petakan untuk membuat kompos. Bahan yang digunakan utuk membuat kompos adalah bahan-bahan yang baik hal ini dikarenakan kompos yang bermutu baik diperoleh dari bahan-bahan yang bermutu baik pula. Selanjutnya pada hari demonstrasi dilakukan, bahan-bahan hijauan dicacah untuk mempercepat proses dekomposisi kompos. Dekomposer yang digunakan ialah rizobakteri indigenos yang telah disiapkan di laboratorium Mikrobiologi Fakultas Pertanian Universitas Andalas.

Setelah semua alat dan bahan yang dibutuhkan tersedia, selanjutnya dilakukan pembuatan plot dengan cara membuat lobang pengomposan sebesar $2 \times 2 \mathrm{~m}$ dengan kedalaman 1 meter dan diberi alas plastik terpal (Gambar 2). Selanjutnya masukkan lapisan pertama cincangan daun tithonia hingga sejengkal. Lapisan kedua dimasukkan pupuk kandang hingga sejengkal. Pada lapisan ketiga dimasukkan dedak halus hingga sejengkal. Pada lapisan keempat dimasukkan jerami padi yang sudah dihaluskan hingga sejengkal. Kemudian siram lapisan kompos dengan rizobakteri secara merata. Kemudian ulangi langkah dari lapisan pertama hingga lapisan keempat sampai lobang terisi penuh. Lalu lubang ditutup dengan terpal plastik hingga rapat.

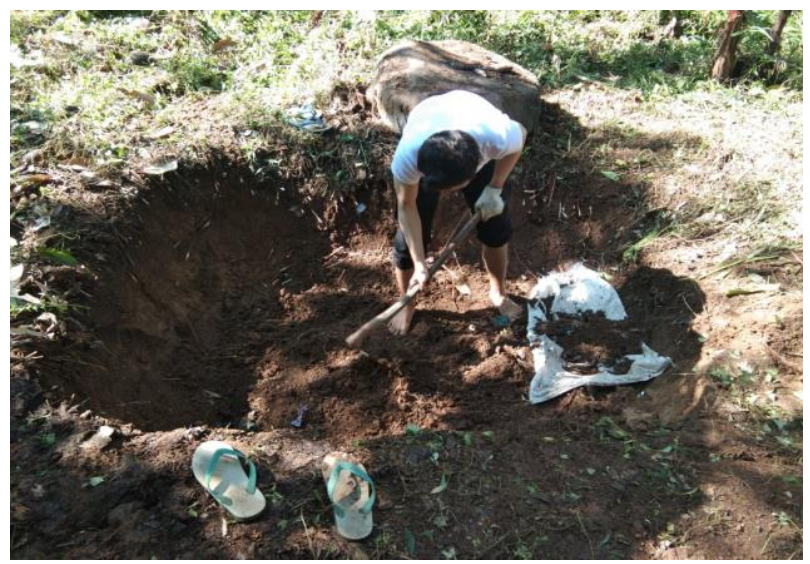

Gambar 2. Demplot untuk pembuatan kompos dengan ukuran $2 \times 2 \times 1$ meter

Setelah proses pembuatan selesai, dilakukan juga proses pengontrolan sekali seminggu untuk memastikan proses fermentasi terjadi dengan baik pada kompos yang dibuat dengan langkah- langkahnya yaitu buka plastik terpal penutup kompos dan diamkan selama beberapa jam untuk menghilangkan gas amonia. Kemudian lakukan pembalikan kompos sampai ke lapisan dasar sehingga bahan-bahan tercampur rata dan disirami lagi dengan rizobakteri sebanyak 10 liter. Kemudian tutup kembali hingga rapat (Gambar 3). Pengontrolan dilakukan sebanyak 3 kali dan pada pengontrolan ke-3 tidak lagi dilakukan penyiraman rizobakteri. Cuaca juga harus diperhatikan, apabila hari hujan jangan sampai terdapat genangan air disekitar pengomposan.

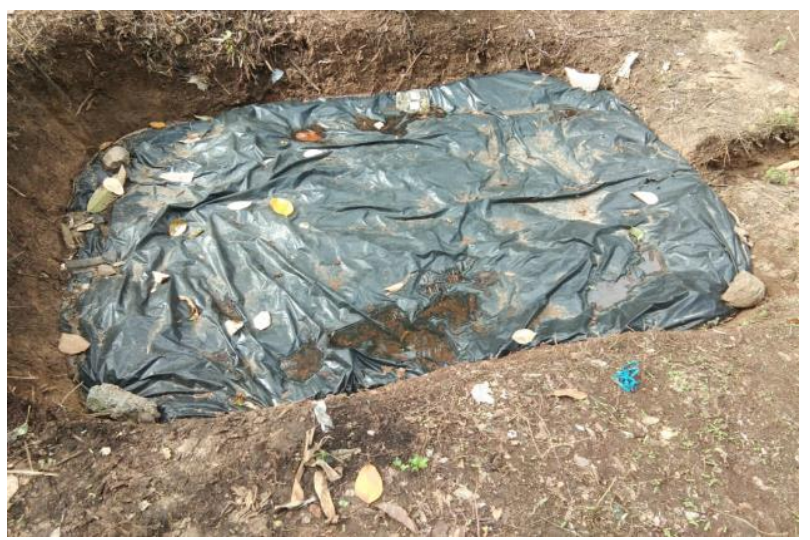

Gambar 3. Kompos yang telah berumur satu minggu setelah dibuat untuk dilakukan pengontrolan.

Kompos yang telah cukup matang ditandai dengan adanya perubahan fisik pada bahan yang digunakan. Perubahan itu antara lain: a). semua bahan pembawa pupuk yang telah difermentasikan berwarna coklat kehitam-hitaman, b). Lunak dan mudah dihancurkan, c). Suhu tumpukan mendekati suhu awal pengomposan, d). Tidak berbau menyengat, e). Volume menyusut hingga setengahnya (Gambar 4) 


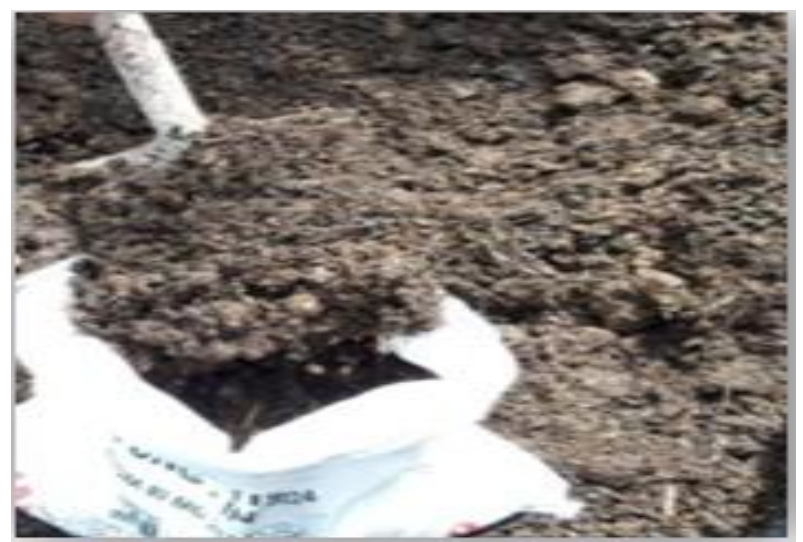

Gambar 4. Kompos yang telah matang yang siap untuk diaplikasikan langsung ke lapangan

\section{KESIMPULAN}

Kegiatan ini sangat bermanfaat bagi masyarakat khususnya kelompok tani Sawah Payo. Antusias dan partipasi aktif dari masyarakat sangat menunjang keberhasilan dari kegiatan ini. Keberhasilan dari pembuatan kompos ditandai dengan adanya perubahan fisik pada bahan yang digunakan. Perubahan itu antara lain: a). semua bahan pembawa pupuk yang telah difermentasikan berwarna coklat kehitam-hitaman, b). Lunak dan mudah dihancurkan, c). Suhu tumpukan mendekati suhu awal pengomposan, d). Tidak berbau menyengat, e). Volume menyusut hingga setengahnya. Kompos yang telah berhasil dapat diaplikasikan langsung kelapangan atau ke lahan petani sawah sebelum proses penanaman dilakukan. Pupuk kompos ini dapat dijadikan sebagai sumber penambahan pendapatan petani padi. Dengan pemberian rhizokompos dapat meningkatkan pertumbuhan tanaman dan mengurangi penggunaan pupuk sintetik.

\section{UCAPAN TERIMAKASIH}

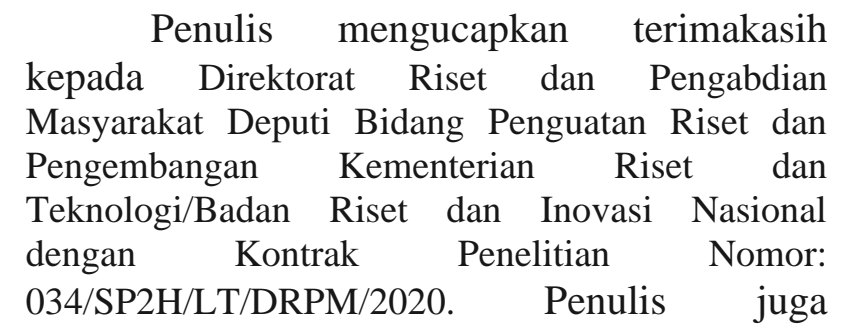

mengucapkan terimakasih kepada Universitas Andalas yang telah mendukung berjalannya program ini. Ucapan terimakasih juga penulis sampaikan kepada Wali Nagari, staf pemerintahan dan seluruh masyarakat Nagari Gunung Rajo terutama kelompok tani sawah Payo yang telah membantu mensukseskan kegiatan pengabdian ini, sehingga kegiatan dapat berjalan dengan baik.

\section{REFERENSI}

Djuarnani, N., Kristian, B. S. Setiawan. 2005. Cara Cepat Membuat Kompos. Agromedia Pustaka. 74 hal.

Kaya, E. 2013. Pengaruh Kompos Jerami Dan Pupuk Npk Terhadap N-Tersedia Tanah, Serapan-N, Pertumbuhan, Dan Hasil Padi Sawah (Oryza Sativa L). Agrologia, Vol. 2, No. 1, April 2013, Hal. 43-50

Lestari AP. 2009. Pengembangan pertanian berkelanjutan melalui substitusi pupuk Anorganik dengan pupuk organik. Jurnal Agronomi. 13(1): 38-47

Prihandarini, R. 2005. Wirausaha Berbasis Pengelolaan Limbah Organik. Bagpro PKSDM Ditjen Dikti Depdiknas dengan Fakultas Pertanian Universitas Brawijaya, Malang.

Wijayanto H, Riyanto D, Triono B. 2018. Desiminasi Produk Teknologi Mesin Pengolah Pupuk Organik Desa Jati Malang Kecamatan Arjosari Kabupaten Pacitan. Wikrama Parahita Jurnal Pengabdian Masyarakat. 2(1):1-5.

Yanti, Y., Busniah. M., Syarif, A., 2014. IbM Pengelolaan Hama Dan Penyakit Tanaman Berbahan Baku Lokal Di Nagari Salimpat Untuk Meningkatkan Produksi Sayuran Serta Pendapatan Petani. Laporan Pengabdian Kepada masyarakat Iptek Bagi Masyarakat 2014.

Yanti, Y. Mayerni, R., Yusniwati, 2015. IbM Pemanfaatan Mikroorganisme Lokal Untuk Mengendalikan Hama Dan Penyakit Tanaman Bawang Merah Di

$$
\text { Teknologi Tepat Guna }
$$


Nagari Aie Dingin. Laporan Pengabdian kepada Masyarakat Tahun 2015.

Yanti, Y., Busnah, M., Syarief, Z., 2017. Pemberdayaan Masyarakat Melalui Budidaya Tanaman Palawija Dengan Aplikasi Teknologi Rizobakteri Indigenos Dan Pemanfaatan Limbah Serta Pengolahan Hasil Produksinya Di Nagari Sungai Durian Kabupaten
Solok. Laporan Pengabdian Kepada Masyarakat KKN PPM

Kemnristekdikti Tahun 2017.

Yanti, Y dan Hamid, H. 2019. Rizokompos dan Pestisida Nabati untuk Petani Sejahtera. Padang: LPPM Universitas Andalas 